\title{
Teaching Reform Practice on University Computer Foundation
}

\author{
Ying $\mathrm{Li}^{1,}$ a , Chunhong Wang ${ }^{2, b}$ \\ ${ }^{1}$ Institute of Information Science and Engineering,Hebei University of Science and \\ Technology,Shijiazhuang,050018,China \\ ${ }^{2}$ Institute of Information Science and Engineering,Hebei University of Science and \\ Technology,Shijiazhuang,050018,China \\ aemail: jszxly@126.com, bemail:hongxue22@sina.com
}

\begin{abstract}
Keywords: Computational thinking; University computer foundation; Teaching reform; Classified teaching
\end{abstract}

Abstract. University computer foundation is a required course in all domestic universities. Based on the features of computer basis teaching, this paper analyzes its actualities and problems, discusses its developing trend and puts forward the corresponding measures. Based on the computational thinking of university computer foundation teaching reform, classification teaching method can train students to develop computational thinking, improve the comprehensive quality and innovative ability, excavate students' learning potential. And it fully arouses the enthusiasm of student's study.

\section{Introduction}

In today's rapid development in information technology, basic computer education is one of the most important basic educations for 21st century's college students.The university computer foundation is the first computer public foundation course. Course training goal is to require students to master the basic knowledge of computer science and technology. Students have the ability to analyze and solve problems. The tertiary institutions should reform the computer education so as to improve students' information quality as a whole.

In October 2009, the ministry of education of higher learning basic computer courses teaching steering committee released the development strategy study basic computer teaching in universities and computer course teaching basic requirements. They put forward several ideas to deepening the reform of computer basis teaching, further defined the fundamental status of basic computer teaching in higher education. Higher learning basic computer courses teaching steering committee requires continuously explore classification teaching mode, strengthen the construction of courses on the basis of the knowledge system and experiment system, strengthen the practice teaching. They put forward the $1+\mathrm{X}$ curriculum system[1], 1 is university computer basic course. It occupies an extremely important status in computer basic teaching. University computer foundation is an important course to cultivate college students' comprehensive quality and innovative ability.

Under the new situation, the connotation of basic computer teaching is rapidly increasing. Further promote the teaching reform of computer basic education to adapt to the trend of the development of computer science and technology is the major requirement of national innovation strategy.

\section{The Current Situation of The University Computer Foundation Course}

The objective of the higher education reforms is to cultivate students' comprehensive quality and ability.Computer basic teaching as an important part of undergraduate education and teaching, expands the computer application ability of students, and improves students' comprehensive quality and innovation practice ability.

In 2006, professor Jeannette m. Wing at Carnegie Mellon university in the United States, defined computational thinking in the journal of the American computer authority communications of the 
ACM. Computational thinking is calculated by using the basic concept of the computer science problem solving system design as well as the breadth of understanding human behavior and other covers computer science in a series of thinking activity[2]. Computational thinking will be a fundamental skill used by everyone in the world by the middle of the 21st Century.Computing and computers will enable the spread of computational thinking.

Afterwards, aiming at the problem of computing education appeared, in 2007 NSF launched basic scientific research program-Pathways to Revitalized Undergraduate Computing Education(CPATH). The basic scientific research program clearly put forward to calculate thinking as the core to the American college of computing education reform. At present, more than 70 us universities took part in the plan[3].

In July 2010, China's nine universities in xi'an on computational thinking and university computer foundation teaching has carried on the discussion, published nine schools Union (C9) computer basic teaching strategy joint statement. The main points of the statement is must recognize the important status of university computer foundation teaching. Training students' ability of computational thinking is the core of computer basic teaching task. A more perfect basic computer course system and teaching content set up benchmark for university computer foundation teaching reform[4].

Ministry of education of college computer foundation course teaching steering committee proposed the university computer foundation teaching is to train students' cognitive ability, use a computer to solve the problem ability, coordination ability and lifelong learning ability. The four factors of ability is the core of computational thinking ability training.

Ministry of education of college computer foundation course teaching steering committee, director of the committee member of Chen guoliang academicians gives some suggestions on the teaching methods.Based on classical cases and the understanding of the basic principle, through the experiment we improve students' ability of computational thinking[5].

In recent years, with the application of computer technology, there have been some problems in the teaching of college computer basic courses, such as teaching content mainly introduces operational knowledge.Aiming at some problems, the university computer foundation curriculum reform is imperative.

\section{Based on Computational Thinking of University Computer Foundation Teaching Reform Pratice}

According to the survey,the freshmen had some basic knowledge of computer and information, they didn't content about the request of computer and information for college students, desired to learn more. Based on computational thinking in college computer basic teaching process, teachers define tasks by using computational thinking, task presentation, task implementation and summary of evaluation. Teachers provide effective information for students to finish learning task. With the help of the teacher students construct their own learning mode and complete the teaching mission. Through this study, students can better use of computational thinking method for autonomous learning. Students learn from each other at the same time. The students' ability of using computer knowledge to solve problems is improved.

A. Based on the subject differences of classified teaching

According to different disciplines in computer teaching, teachers use examples to introduce the application of computers in different disciplines and the methods to solve the problem. Based on computational thinking classification teaching is beneficial to students' understanding of computer applications.

Based on computational thinking basic computer courses teaching content divided into science and liberal arts classes. Classified teaching make the students to be innovative talents, with computational thinking ability, innovation ability, the comprehensive application ability and basic computer skills. Teachers teach students in accordance with their aptitude and arrange contents of practice teaching reasonably according the students' real situation. Tasks should be arranged with different levels of difficulty and various forms connecting closely with knowledge points in 
textbooks.

Teachers give the students full time to solve the problems which are different from that teachers are teaching. Students can design tasks related to their subjects. The process obeys the principle “computational thinking” from start to the end so as to guiding students to accomplish the process from comprehending the question,conceiving, designing and implementing to operating. So it develops students' interests to learn initiatively and trains their ability to create and analyze and solve problems, as well as having the disseminated knowledge learned and understood.

B. The teaching content is heuristic and exploratory

University computer foundation course teaching content includes overview of computer, data representation and storage, computer systems, operating system, computer network foundation and application, algorithm and program design basis, database system and information security. Students master the computer basic operation skills through the experiment. Science students learn algorithm and program design basis. Liberal arts students learn database system.

The heuristic method of teaching is a high efficiency teaching method. Heuristic teaching is propitious to cultivating students' ideation. Based on computational thinking, teachers guide students to analyze problems and master the computational principle. Through the abstraction and automation, student form the thinking of problem solving. The various tasks of teaching are accomplished by the interaction between teacher and students. Teachers guide students to active thinking and discussion. Students are encouraged to explore the solution of the problem.

Computer overview include neumann von computer model, stored procedures and verification code. Basic composition principle of computational thinking mainly includes the decimal-binary conversion and composition of the computer. Based on computational thinking, operating system has many examples such as virtual machine. In the network topologies, network architecture, network hardware equipment and network addressing, computer network reflect the thought of the computational thinking. About information security, teachers introduce captcha.

C. Strengthen the practical teaching

The practical teaching has the direct influence on the teaching effect. The practical teaching should be strengthened to train and improve computer application ability of students. It is an important link of teaching reform to implement quality education. The practical teaching is on the basis of the effective management and use of the lab equipment.

To cultivate the computer basic skills and comprehensive ability of students, experiment content is divided into basic experiment, expanded experiment and innovative experiment. Some outstanding students are encouraged to have their own originality and independently complete the innovative experiment of higher level, thus the effect of practice teaching has been improved. Classified teaching mode and a series of experimental training improve the students' information literacy. Through local area network (LAN) access to the Internet, laboratory formed the open teaching environment. Laboratory installed multimedia teaching system. Computational thinking ability of students is improved.

D. All-round learning resources

Education of 21st century requires higher learing institutes to provide the society with all-round talents. It is the key step to deepen the higher education reform and establish a model which can foster high-qualified talents by means of information technology, including computer network.In the network teaching system, all-round learning resources is established. Teachers can publish job on the Internet and answer questions. Through the autonomous learning, students could improve the ability of information literacy and computational thinking.

Network teaching system provides abundant information resources. Teachers choose resources and enhance the network real-time interaction. Computational thinking ability of students is improved. Open educational resources are learning materials that have been released under an intellectual property license such as creative commons or in the public domain that allows their free use by others.

The teaching contents are timely updated. The teaching content is extended as much as possible to satisfy students. The basic computer courses that based on the network aided 
teaching platform of Internet have complete contents, outstanding interaction of teacher-students, remarkable teaching effect. They were praised by the school as the teaching demonstration courses.

E. Course assessment

Course assessment is an important link in course construction. The objectives of course assessment are: to evaluate to what extent the students have understood what they have learnt, by which to make students study more effectively and have an all around growth.

We have established examination system, gradually realize the teaching and examination separated. Through carefully designed examination content,we test students' ability in computer operation and solve problems. In hebei province computer rank examination once a year, students get the best grades. It has a positive impact on promoting the education reform, improving the course construction's level, accelerating the modernization process of education and improving students' practice ability . The assessment will be good for their further study.

\section{Conclusion}

Based on computational thinking, university computer teaching reform use tasks and classified teaching method. It improves the students' ability to analyze and solve problems, develop students' computational thinking and information literacy. Students understand the basic content of computational thinking and the calculation of the general steps to solve the problem of thinking. University computer foundation teaching reform will continue to improve the students' thinking ability and innovation ability.

\section{Acknowledgement}

In this paper, the research was sponsored by the College Information Science and Engineering Teaching and Research Project of Hebei University of Science and Technology (Project No. 2012Z02).

\section{References}

[1] The ministry of education of higher learning basic computer courses teaching steering committee. Development strategy study basic computer teaching in universities and computer course teaching basic requirements. Beijing: higher education press. 2009.

[2] Jeannette M. Wing. Computational Thinking [J]. Communications of the ACM .2006: 49 (3): 33-35

[3] Rongsheng Dong. Nine schools league joint statement (C9) computer basis teaching development strategy: the transformation of education $[\mathrm{J}]$. Journal of China university teaching. 2010 (10) 14-15

[4] Qinming He, Hanquan Lu, Boqin Feng. The core task of the computer foundation teaching is to the ability of computational thinking [J]. Journal of China university teaching . 2010 (9) 5-9

[5] Guoliang Chen, Rongsheng Dong. Computational thinking and university computer basis education [J]. Journal of China university teaching .2011 (1) 7-11. 